\title{
Chronic lymphocytic leukemic cells exhibit apoptotic signaling via TRAIL-R1
}

\author{
M MacFarlane ${ }^{1,3}$, S Inoue ${ }^{1,3}$, SL Kohlhaas ${ }^{1}$, A Majid ${ }^{1}$, N Harper ${ }^{1}$, \\ DBJ Kennedy ${ }^{2}$, MJS Dyer ${ }^{1,2}$ and GM Cohen*,1 \\ ${ }^{1}$ MRC Toxicology Unit, Hodgkin Building, University of Leicester, Lancaster \\ Road, Leicester, UK \\ ${ }^{2}$ Department of Hematology, University of Leicester, Leicester Royal Infirmary, \\ Leicester, UK \\ 3 Joint first authors \\ * Corresponding author: GM Cohen, MRC Toxicology Unit, Hodgkin Building, \\ University of Leicester, PO Box 138, Lancaster Road, Leicester, LE1 9HN, UK \\ Tel: +44 116 2525601; Fax: + 44116 2525616; E-mail: gmc2@le.ac.uk
}

Received 22.3.05; revised 24.3.05; accepted 25.3.05; published online 29.4.05 Edited by A Finazzi-Agrò

\begin{abstract}
Clinical trials have been initiated with Apo2L/TRAIL (Genentech) and agonistic mAbs to TRAIL receptors, -R1 and -R2 (Human Genome Sciences). The apoptosis-inducing ability of these mAbs and different TRAIL preparations, in the presence or absence of histone deacetylase inhibitors (HDACi), varied markedly against primary chronic lymphocytic leukaemia (CLL) cells and various tumor cell lines, demonstrating an unanticipated preferential apoptotic signaling via either TRAIL-R1 or -R2. Contrary to literature reports that TRAIL-induced apoptosis occurs primarily via signaling through TRAIL-R2, CLL cells, in the presence of $\mathrm{HDACi}$, undergo predominantly TRAIL-R1mediated apoptosis. Consequently, Apo2L/TRAIL, which signals primarily through TRAIL-R2, is virtually devoid of activity against CLL cells. To maximize therapeutic benefit, it is essential to ascertain whether a primary tumor signals via TRAIL-R1/-R2, prior to initiating therapy. Thus combination of an agonistic TRAIL-R1 Ab and an HDACi, such as the anticonvulsant sodium valproate, could be of value in treating CLL. Cell Death and Differentiation (2005) 12, 773-782.

doi:10.1038/sj.cdd. 4401649

Published online 29 April 2005
\end{abstract}

Keywords: chronic lymphocytic leukaemia; tumor necrosis factor-apoptosis inducing ligand; TRAIL-R1; histone deacetylase inhibitors

Abbreviations: CLL, chronic lymphocytic leukaemia; DISC, death-inducing signaling complex; $\mathrm{HDACi}$, histone deacetylase inhibitor; HGS, Human Genome Sciences; TRAIL, TNF-related apoptosis-inducing ligand; TRAIL-R1, TRAIL-receptor 1; TRAIL-R2, TRAIL-receptor 2

\section{Introduction}

TNF-related apoptosis-inducing ligand (TRAIL), a member of the TNF family, is being developed as an antitumor agent as it induces apoptosis in a wide range of tumor cell lines but not in most normal cells. ${ }^{1-4}$ TRAIL induces apoptosis by binding to two membrane-bound receptors, TRAIL-R1 (DR4) and TRAIL-R2 (DR5/TRICK2), resulting in the recruitment of the adaptor molecule FADD/MORT1, followed by the recruitment and activation of caspase-8, into the death-inducing signaling complex (DISC) ${ }^{5-7}$ Active caspase-8, the apical caspase in death receptor-induced apoptosis, can then activate other caspases, such as caspase- 3 , which in turn cleave many cellular substrates resulting in the biochemical and morphological features characteristic of apoptosis. ${ }^{8}$

TRAIL is particularly promising for development as an anticancer agent as it appears to be nontoxic to normal tissues in contrast to other members of the TNF family, such as TNF or CD95, which cause systemic inflammatory syndrome and liver toxicity, respectively. ${ }^{9-11}$ Despite its early promise since its discovery in 1995, TRAIL is only now entering Phase I clinical trials partly due to reports of its potential liver toxicity. ${ }^{12}$ Also, although many cancer cell lines show sensitivity to TRAIL, many primary cells from patients, such as those with chronic lymphocytic leukemia (CLL) and B-cell non-Hodgkin's lymphoma, are commonly resistant to TRAIL-mediated apoptosis. ${ }^{13-15}$ Although in many of these cells the mechanism(s) of TRAIL resistance is unclear, use of a combination of treatments with either chemotherapeutic agents or irradiation may sensitize tumor cells to TRAIL. $9,11,16$

We have shown that resistance of CLL cells to TRAIL-induced apoptosis is upstream of caspase-8 activation at the level of the DISC. ${ }^{14}$ More recently we have shown that low concentrations of histone deacetylase inhibitors (HDACi) sensitize CLL cells to TRAIL-induced apoptosis by facilitating increased formation of the TRAIL DISC. ${ }^{17}$ We proposed that the combination of $\mathrm{HDACi}$ and TRAIL agonists could be of therapeutic benefit in CLL as well as other TRAIL-resistant hematological malignancies. The combination of TRAIL with HDACi may be particularly valuable as $\mathrm{HDACi}$ are reported to be relatively nontoxic. ${ }^{18,19}$

In this study, we investigated the ability of different forms of TRAIL and agonistic Abs to induce apoptosis in a panel of cell lines and primary cells from patients with CLL in the presence or absence of HDACi. The different forms of TRAIL and Abs included those currently in Phase I and II clinical trials. namely Apo2L/TRAIL (Genentech), ${ }^{2,3}$ HGS-ETR1 and HGS-ETR2 (Human Genome Sciences), ${ }^{20-22}$ as well as TRAIL-His-LE (a recombinant TRAIL with low endotoxin) or TRAIL-His (recombinant TRAIL used in our previous study but not further purified to reduce endotoxin levels). ${ }^{14,17,23}$

\section{Results}

HDACi sensitize CLL cells to TRAIL primarily via TRAIL-R1

Recently, we have shown that pretreatment of CLL cells with $\mathrm{HDACi}$, such as depsipeptide or Trichostatin A, sensitizes resistant cells to TRAIL-induced apoptosis. ${ }^{17}$ In order to 
exploit this observation clinically, we wished to identify which form of TRAIL and which HDACi would have optimal biological activity and could therefore be used in an initial clinical trial.

Peripheral blood lymphocytes from 28 patients with CLL at different clinical stages were studied. The clinical charac- teristics of these patients are shown in Table 1. Cells from 10 of these patients have been characterized more extensively in terms of sensitivity to the different forms of TRAIL and are depicted in Figure 1a.

Spontaneous apoptosis in freshly isolated CLL cells from different patients varied significantly $(3.4-46 \%, n=28)$ after

Table 1 Summary of data from 28 patients with CLL

\begin{tabular}{|c|c|c|c|c|c|c|c|c|c|c|}
\hline $\begin{array}{l}\text { Patient } \\
\text { number }\end{array}$ & $\begin{array}{l}\text { Age / } \\
\text { sex }\end{array}$ & $\begin{array}{l}\text { Binet } \\
\text { stage }\end{array}$ & Prior therapy & $\begin{array}{c}\text { FAMP } \\
\text { resistance }\end{array}$ & $\begin{array}{l}\text { WCC } \\
\times 10^{9} / \mathrm{l}\end{array}$ & $\begin{array}{c}\% \text { IGHV } \\
\text { homology }\end{array}$ & $\begin{array}{l}\text { IGHV } \\
\text { gene } \\
\text { family }\end{array}$ & $\begin{array}{l}\text { p53 } \\
\text { mutation }\end{array}$ & $\begin{array}{c}\% \\
\text { Spontaneous } \\
\text { apoptosis }\end{array}$ & $\begin{array}{c}\% \\
\text { Apoptosis: } \\
\text { TRAIL plus } \\
\text { HDACi }\end{array}$ \\
\hline 1 & $66 / \mathrm{M}$ & $A$ & NIL & $\mathrm{N} / \mathrm{A}$ & 28 & 90 & $3-33$ & & 22.9 & 64.2 \\
\hline 2 & $44 / F$ & $A(P)$ & NIL & $\mathrm{N} / \mathrm{A}$ & 126 & 88 & $4-34$ & & 41.2 & 80.8 \\
\hline 3 & 71/M & $\mathrm{C}^{\prime}$ & $\begin{array}{l}\text { FAMP } \\
\text { FAMP + } \\
\text { CAMPATH-1H }\end{array}$ & Yes & 52 & 99 & $1-69$ & & 22.2 & 68.9 \\
\hline 4 & $76 / \mathrm{M}$ & $B$ & $\begin{array}{l}\text { FAMP + } \\
\text { cyclophosphamide } \\
\text { (NR) }\end{array}$ & Yes & 106 & 100 & 3-09 & $\begin{array}{l}\text { CODON } 193 \\
\text { His } \rightarrow \text { Leu }\end{array}$ & 46.2 & 88.7 \\
\hline 5 & 83/F & $A(P)$ & $\begin{array}{l}\text { Chlorambucil } \times 2 \\
\text { courses }\end{array}$ & N/A & 52 & 88 & $3-30$ & & 27.2 & 55.9 \\
\hline 6 & 78/M & $A(P)$ & $\begin{array}{l}\text { Chlorambucil } \times 2 \\
\text { courses }\end{array}$ & $\mathrm{N} / \mathrm{A}$ & 113 & 96 & $2-05$ & & 9.7 & 49.8 \\
\hline 7 & 68/M & $B$ & FAMP & N/A & 332 & 100 & $4-59$ & & 32.1 & 63.2 \\
\hline 8 & $57 / \mathrm{M}$ & $\mathrm{C}$ & NIL & $\mathrm{N} / \mathrm{A}$ & 156 & 97 & $3-53$ & & 43.7 & 85.8 \\
\hline 9 & $66 / \mathrm{M}$ & $\mathrm{C}$ & $\begin{array}{l}\text { Chlorambucil } \times 2 \\
\text { courses }\end{array}$ & No & 110 & 86 & $4-34$ & & 23.8 & 49.8 \\
\hline 10 & $85 / F$ & C & $\begin{array}{l}\text { Chlorambucil } \\
\text { FAMP }\end{array}$ & Yes & 144 & 92 & $3-30$ & $\begin{array}{l}\text { CODON } 266 \\
\text { (Gly } \rightarrow \text { Arg) } \\
\text { CODON } 267 \\
(\text { Arg } \rightarrow \text { Trp) }\end{array}$ & $\begin{array}{l}25.5 \\
37.1\end{array}$ & $\begin{array}{l}73.1 \\
58.2\end{array}$ \\
\hline 11 & $69 / \mathrm{M}$ & $A$ & NIL & N/A & 50 & 96 & $1-69$ & & 5.8 & 38.6 \\
\hline 12 & $62 / F$ & A & NIL & $\mathrm{N} / \mathrm{A}$ & 128 & 88 & $3-64$ & & 8.1 & 18.6 \\
\hline 13 & $74 / \mathrm{M}$ & $A(P)$ & NIL & $\mathrm{N} / \mathrm{A}$ & 82 & 96 & $4-34$ & & 9.9 & 11.2 \\
\hline 14 & $64 / M$ & C & $\begin{array}{l}\text { Chlorambucil } \\
\text { FAMP } \\
\text { FAMP + } \\
\text { Cyclophosphamide } \\
\text { CHOP } \\
\text { FAMP + } \\
\text { CAMPATH-1H }\end{array}$ & Yes & 257 & 98 & $3-21$ & & 20.3 & 65.8 \\
\hline 15 & $60 / \mathrm{M}$ & C & $\begin{array}{l}\text { Chlorambucil } \\
\text { CAMPATH-1 H + } \\
\text { FAMP }\end{array}$ & Yes & 353 & 99 & $1-69$ & $\begin{array}{l}\text { One allele } \\
\text { deleted by } \\
\text { FISH assay } \\
\text { but no } \\
\text { mutation } \\
\text { detected }\end{array}$ & 14.1 & 71.7 \\
\hline 16 & $76 / F$ & C & FAMP & No & 87 & 99 & $4-39$ & & 22.9 & 76.7 \\
\hline 17 & $82 / F$ & $A(P)$ & Chlorambucil & N/A & 89 & 90 & $3-30$ & & 26.0 & 68.2 \\
\hline 18 & $72 / \mathrm{M}$ & $\mathrm{C}$ & $\begin{array}{l}\text { Chlorambucil } \\
\text { FAMP } \\
\text { FAMP + } \\
\text { CAMPATH-1H }\end{array}$ & Yes & 175 & 99 & $1-69$ & & 17.3 & 74.4 \\
\hline 19 & $47 / \mathrm{M}$ & C & FAMP & No & 250 & 99 & $1-02$ & & 19.7 & 64.4 \\
\hline 20 & $84 / \mathrm{M}$ & $\mathrm{C}$ & $\begin{array}{l}\text { Chlorambucil } \times 3 \\
\text { courses }\end{array}$ & $\mathrm{N} / \mathrm{A}$ & 314 & 98 & $3-21$ & & 27.1 & 80.5 \\
\hline 21 & $66 / M$ & $A(P)$ & NIL & $\mathrm{N} / \mathrm{A}$ & 119 & 100 & 3-09 & & 19.6 & 64.4 \\
\hline 22 & $81 / \mathrm{M}$ & C & Chlorambucil & $\mathrm{N} / \mathrm{A}$ & 159 & 97 & $3-11$ & & 16.1 & 65.9 \\
\hline 23 & $71 / \mathrm{M}$ & $\mathrm{C}$ & FAMP & Yes & 74 & 96 & $1-18$ & & 6.8 & 63.2 \\
\hline 24 & $68 / \mathrm{M}$ & $B$ & NIL & N/A & 28 & 93 & $3-33$ & & 28.3 & 56.9 \\
\hline 25 & $76 / \mathrm{M}$ & A & NIL & N/A & 50 & 95 & 3-09 & & 17.8 & 16.9 \\
\hline 26 & $72 / \mathrm{M}$ & C & $\begin{array}{l}\text { Primary } \\
\text { Chlorambucil } \\
\text { resistant }\end{array}$ & N/A & 147 & 100 & $3-74$ & & 3.4 & 9.3 \\
\hline 27 & $80 / \mathrm{M}$ & $A(P)$ & NIL & $\mathrm{N} / \mathrm{A}$ & 144 & 100 & $3-23$ & & 18.1 & 46.0 \\
\hline 28 & $55 / \mathrm{M}$ & C & $\begin{array}{l}\text { Primary } \\
\text { Chlorambucil } \\
\text { resistant }\end{array}$ & N/A & 280 & 94 & $3-33$ & & 22.2 & 52.7 \\
\hline
\end{tabular}

$A(P)$ denotes progressive Stage A CLL; FAMP denotes fludarabine; N/A denotes not applicable. Patients \#1-12 correspond with the patient data shown in Figure 1ad. The response to HDACi in all patients was measured with TRAIL-His (100 ng/ml). Patient \#10 shows the sensitization data obtained both before and after acquiring a p53 mutation. We define $\geqslant 98 \%$ homology of the $I G V H$ gene to its germline sequence as unmutated 
$16 \mathrm{~h}$ culture in vitro (Table 1). No increase in the spontaneous level of apoptosis was observed in cells from these different patients exposed either to Apo2L/TRAIL (100-4000 ng/ml), TRAIL-His-LE $(100 \mathrm{ng} / \mathrm{ml})$ or TRAIL-His $(100 \mathrm{ng} / \mathrm{ml})$ alone (data not shown). Thus, as shown previously, primary CLL cells are totally resistant to TRAIL-induced apoptosis.

Firstly, we examined if depsipeptide could sensitize to different TRAIL preparations or was limited to a specific property of our own preparation of TRAIL (TRAIL-His). CLL cells were pretreated for $16 \mathrm{~h}$ with depsipeptide $(10 \mathrm{nM})$ and then exposed to the different forms of TRAIL (Figure 1a). Pretreatment with depsipeptide at this concentration did not
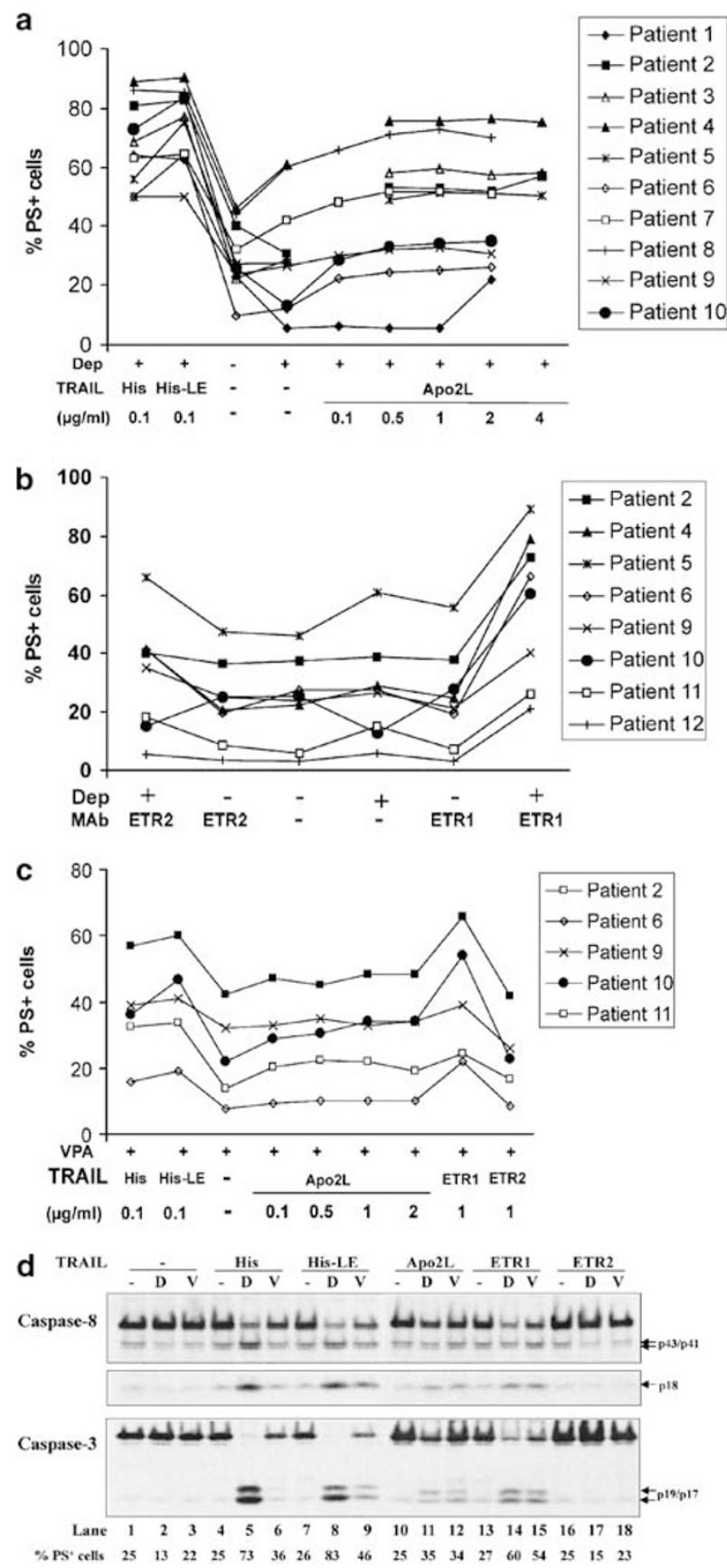

increase the levels of spontaneous apoptosis but markedly sensitized cells from all 10 patients to subsequent exposure to either TRAIL-His-LE $(100 \mathrm{ng} / \mathrm{ml})$ or TRAIL-His $(100 \mathrm{ng} / \mathrm{ml})$ with the TRAIL-LE being slightly more potent in $5 / 10$ patients (Figure 1a). Pretreatment with depsipeptide also sensitized CLL cells to Apo2L/TRAIL. However in all 10 patients, the sensitization to Apo2L/TRAIL was always less than that observed with the other forms of TRAIL even when Apo2L/ TRAIL was used at 40-fold greater concentration than TRAILHis-LE (Figure 1a). Although depsipeptide sensitized CLL cells to Apo2L/TRAIL, the dose response curve was relatively shallow and appeared to plateau at concentrations of Apo2L/ TRAIL of $500 \mathrm{ng} / \mathrm{ml}$ with very little increase in sensitization occurring at higher concentrations of Apo2L/TRAIL (2000$4000 \mathrm{ng} / \mathrm{ml}$ ) (Figure 1a).

Secondly, we assessed the activity of agonistic TRAIL receptor $m A$ bs under the same conditions. Two agonistic human IgG1 mAbs, HGS-ETR1, a TRAIL-R1 mAb, and HGSETR2, a TRAIL-R2 mAb, have been developed for potential treatment of certain forms of human cancer and are currently in Phase I or II studies. ${ }^{20-22}$ When used alone, neither HGSETR1 $(1 \mu \mathrm{g} / \mathrm{ml})$ nor HGS-ETR2 $(1 \mu \mathrm{g} / \mathrm{ml})$ induced significant levels of apoptosis in freshly isolated CLL cells from different patients $(n=8)$ (Figure 1b). Pretreatment of CLL cells for $16 \mathrm{~h}$ with depsipeptide $(10 \mathrm{nM})$ clearly sensitized CLL cells to apoptosis induced by HGS-ETR1, whereas little if any sensitization was observed with HGS-ETR2 (Figure 1b). The $\%$ apoptosis in the presence of depsipeptide either alone $(26.9 \pm 16$ Mean \pm S.E.M., $n=8)$ or together with HGS-ETR1 or HGS-ETR2 were $56.7 \pm 23$ or $32.8 \pm 17$, respectively (Mean \pm S.E.M., $n=8$ ). These results strongly suggested that TRAIL-induced apoptosis in CLL cells occurred primarily by signaling through TRAIL-R1.

We also wished to determine if CLL cells could be similarly sensitized to TRAIL by sodium valproate, as this is a widely used anticonvulsant drug with relatively little toxicity. Valproate also has activity as an $\mathrm{HDACi}^{24,25}$ and so could be used in a clinical trial in combination with either TRAIL or agonistic mAbs without the problems associated with using two novel

Figure 1 Potentiation of TRAIL-induced apoptosis in CLL cells by HDAC inhibitors occurs primarily by signaling through TRAIL-R1. (a) Freshly isolated and purified CLL cells from 10 individual patients, corresponding to the appropriate patient number in Table 1, were either incubated alone (Con) or preincubated for $16 \mathrm{~h}$ with depsipeptide (Dep) $(10 \mathrm{nM})$. The cells were then treated for a further $4 \mathrm{~h}$ with TRAIL-His $(100 \mathrm{ng} / \mathrm{ml})$, TRAIL-His-LE $(100 \mathrm{ng} / \mathrm{ml})$ or Apo2L/TRAIL (Apo2L) (100-4000 ng/ml) and apoptosis assessed by measurement of phosphatidylserine (PS) externalization as described in Methods. Each line in Figure 1 (a-c) represents data from an individual patient. (b) CLL cells from different patients were preincubated for $16 \mathrm{~h}$ either alone or with depsipeptide (Dep) $(10 \mathrm{nM})$ and then treated for a further $4 \mathrm{~h}$ with HGS-ETR1 (ETR1) $(1 \mu \mathrm{g} / \mathrm{ml})$ or HGS-ETR2 (ETR2) $(1 \mu \mathrm{g} / \mathrm{ml})$ and apoptosis measured by PS externalization. (c) CLL cells from different patients were preincubated for $16 \mathrm{~h}$ with sodium valproate (VPA) $(2 \mathrm{mM})$ and then treated for a further $4 \mathrm{~h}$ with the different preparations of TRAIL or with the agonistic mAbs as indicated in (a) and (b) above. Apoptosis was measured by PS externalization. (d) Apoptosis was also assess by measuring processing of caspase- 8 and -3 in cells obtained from one patient (\#10) treated with depsipeptide (D) or valproate (V) as described above in $(\mathbf{a}-\mathbf{c})$. Very similar data were obtained using cells, from another patient, exposed to all the different preparations. Similar results were also obtained when the effects of individual TRAIL preparations or Abs on cells from at least another five different patients were examined 
agents in a clinical trial. Valproate $(2 \mathrm{mM})$ alone induced little or no apoptosis in CLL cells $(23.5 \pm 12$, Mean \pm S.E.M., $n=5$ ) and sensitized CLL cells to TRAIL-induced apoptosis (Figure 1c). Interestingly, the magnitude of the valproate-mediated sensitization of CLL cells to HGS-ETR1 $(41 \pm 16$, Mean \pm S.E.M., $n=5)$ was essentially identical to its sensitization to TRAIL-His-LE $(40.1 \pm 13$, Mean \pm S.E.M., $n=5)$. Although valproate clearly sensitized CLL cells to HGS-ETR1, it caused no sensitization to HGS-ETR2 $(23.1 \pm 11$, Mean \pm S.E.M., $n=5$ ) (Figure 1c). These results support the suggestion that in CLL cells signaling through TRAIL-R1 is more important than TRAIL-R2 for cell death (Figure 1c).

To confirm that the depsipeptide and valproate-mediated sensitization was due to apoptosis, we examined the effects of the different treatments on the processing of caspase-8, the apical caspase in TRAIL-induced apoptosis, ${ }^{5-7,26}$ and caspase-3 the major effector caspase in many cells including CLL cells undergoing apoptosis. In untreated CLL cells, caspase-3 and caspase- 8 were present as their unprocessed zymogens (Figure 1d lane 1). Exposure of CLL cells to depsipeptide $(10 \mathrm{nM})$, valproate $(2 \mathrm{mM})$, TRAIL-His $(100 \mathrm{ng} / \mathrm{ml})$, TRAILHis-LE (100 ng/ml), Apo2L/TRAIL (2000 ng/ml), HGS-ETR1 $(1 \mu \mathrm{g} / \mathrm{ml})$ or HGS-ETR2 $(1 \mu \mathrm{g} / \mathrm{ml})$ alone neither induced apoptosis nor processing of caspase-3 or caspase-8 (Figure 1d lanes 2-4, 7, 10, 13 and 16). However in CLL cells, pretreated with either depsipeptide or valproate, processing of caspase- 8 both to its p43 and p41 fragments and also its p18 catalytically active large subunit as well as processing of caspase- 3 to its $\mathrm{p} 19$ and $\mathrm{p} 17$ forms was observed in CLL cells exposed to TRAIL-His, TRAIL-His-LE, Apo2L/TRAIL and HGS-ETR1 (Figure 1d lanes 5, 6, 8, 9, $11,12,14$ and 15). The amount of caspase processing was generally commensurate with the induction of apoptosis induced by the different preparations of TRAIL or the mAbs; for example, no apoptosis or processing of caspases was observed with HGS-ETR2 (Figure 1d lanes 17 and 18). Depsipeptide was generally more effective than valproate at potentiating TRAIL-induced-apoptosis and processing of caspases. However, both depsipeptide $(10 \mathrm{nM})$ and valproate (1-2 mM) inhibited HDACs in CLL cells, as assessed by an accumulation of acetylated $\mathrm{H} 3$ and $\mathrm{H} 4$ (data not shown), in agreement with our previous findings ${ }^{17}$ that both depsipeptide and Trichostatin A caused similar effects.

Thus following initial pretreatment with HDACi, the biological activities of different TRAIL preparations varied markedly in their ability to induce apoptosis in CLL cells with the potencies being TRAIL-His-LE $\geqslant$ TRAIL-His $\approx$ HGSETR1 > Apo2L/TRAIL $\gg$ HGS-ETR2. Taken together, these results strongly suggest that in CLL cells signaling to apoptosis occurs almost exclusively via TRAIL-R1 rather than TRAIL-R2.

\section{Sensitization to TRAIL-induced apoptosis by HDACi is p53-independent}

Some interindividual variation was observed in the depsipeptide-mediated sensitization of CLL cells to TRAIL-induced apoptosis (Table 1 and data not shown). The HDACi sensitization appeared to be p53-independent as it was observed in CLL cells from patients with mutated p53 (Table 1). To confirm this, we used HCT116 cells in which the p53 gene is disrupted by homologous recombination. ${ }^{27}$ Pretreatment with depsipeptide sensitized both parental and p53 ${ }^{-1-}$ HCT116 cells to TRAIL-induced apoptosis to a similar extent (Figure 2), confirming that the ability of HDACi to sensitize cells to TRAIL is p53-independent.

Depsipeptide sensitization was effective at inducing apoptosis in patients with advanced CLL. Cells from all eight patients who were resistant to fludarabine or patients who habored p53 mutations were sensitized to TRAIL by depsipeptide (Table 1), suggesting that this combination might be effective in this patient population, which overall has a median survival of about 12 months with conventional chemotherapeutic regimens. ${ }^{28,29}$ One valuable prognostic marker in CLL is the mutation rate within the immunoglobulin variable region (IGHV) gene sequences, with patients lacking mutations having a markedly inferior prognosis to those who do. ${ }^{30,31}$ Significantly, the combination of HDACi and TRAIL was equally effective in both subgroups of CLL (Table 1). Three patients (\#13, 25 and 26) did not show enhanced apoptosis with TRAIL in the presence of HDACi. These patients were heterogeneous in terms of their clinical and IGHV mutational status. The mechanism by which these patients showed resistance to HDACi-mediated sensitization is unknown.

\section{Depsipeptide sensitizes U937 and K562 cells to TRAIL-induced apoptosis}

To examine if similar variations in the efficacy of different TRAIL preparations were also evident in other cell types, we examined the ability of depsipeptide to sensitize both the monoblastic leukemia cell line U937 and the Philadelphia chromosome-positive acute myeloid leukemia cell line K562 using the different TRAIL preparations.

Depsipeptide $(10 \mathrm{nM})$, valproate $(2.5 \mathrm{mM})$, TRAIL-His-LE (100 ng/ml), TRAIL (100 ng/ml), HGS-ETR1 (50-1000 ng/ml) or HGS-ETR2 (50-1000 ng/ml) alone did not induce significant levels of apoptosis in U937 cells as assessed by phosphatidylserine externalization (Figure 3a). Apo2L/TRAIL

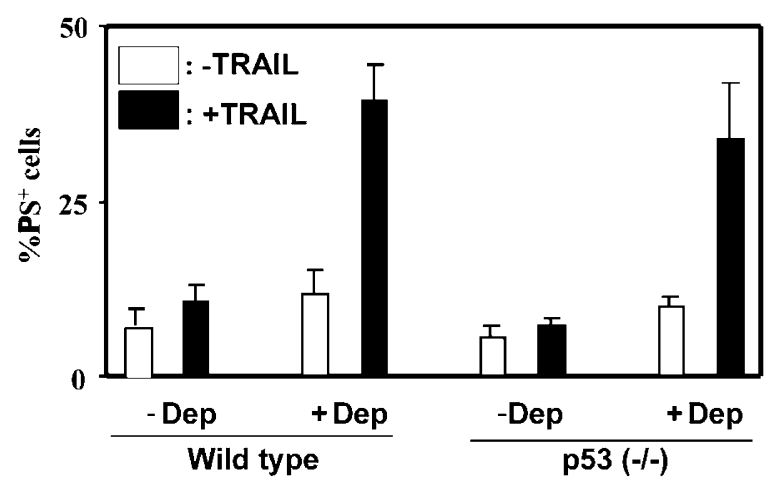

Figure 2 HDACi sensitization to TRAIL-induced apoptosis is p53-independent. Parental and $p 53^{-1-}$ HCT116 cells were incubated for $8 \mathrm{~h}$ with depsipeptide $(10 \mathrm{nM})$ and then exposed to TRAlL-His $(50 \mathrm{ng} / \mathrm{ml})$ for a further $4 \mathrm{~h}$. Apoptosis was then assessed by PS externalization as described in Methods. The results shown represent the Mean \pm S.E.M. of three separate determinations 

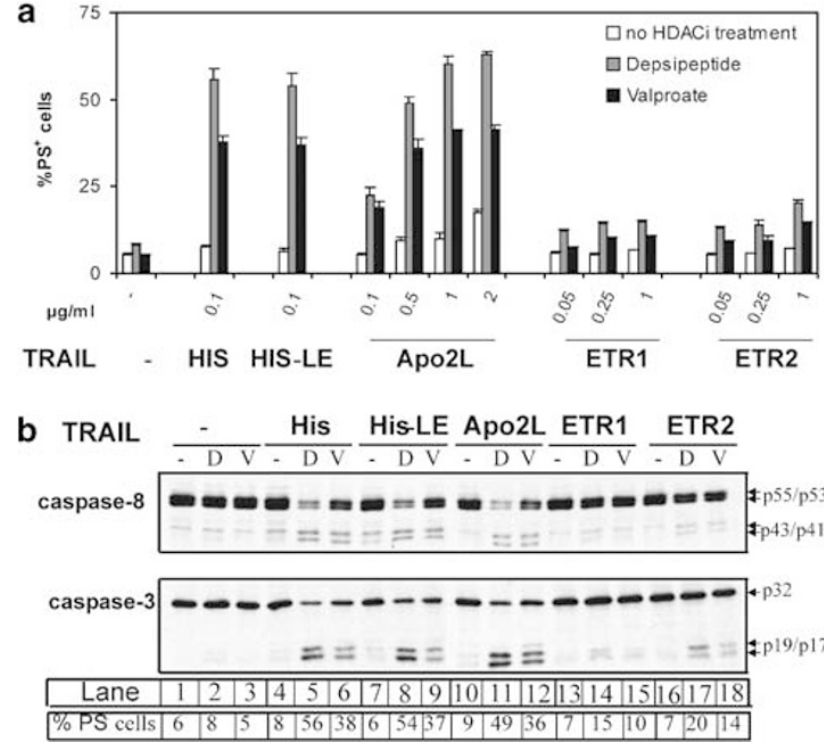

Figure 3 HDAC inhibitors sensitize U937 cells to TRAIL-induced apoptosis. U937 cells were incubated either alone or with depsipeptide (D) $(10 \mathrm{nM})$ or sodium valproate $(\mathrm{V})(2.5 \mathrm{mM})$ for $8 \mathrm{~h}$ and then exposed to TRAIL-His (His), TRAIL-His-LE (His-LE) or Apo2L/TRAIL (Apo2L) or to the agonistic mAbs as described in the legend to Figure 1. (a) Apoptosis was assessed by measurement of phosphatidylserine (PS) externalization. The results shown represent the Mean \pm S.E.M. of three separate determinations. (b) Apoptosis was also assessed by processing of caspase- 8 and -3

$(100 \mathrm{ng} / \mathrm{ml})$ alone did not induce any apoptosis but higher concentrations $(500-2000 \mathrm{ng} / \mathrm{ml})$ caused a modest concentration-dependent induction of apoptosis (Figure 3a). Pretreatment with depsipeptide or valproate sensitized U937 cells to the different TRAIL preparations but had only very modest effects with the agonistic Abs (Figure 3a). The reasons for the modest potentiation of the Abs are unclear. Depsipeptide was more effective than valproate in sensitizing the cells $(P \leqslant 0.05)$. The extent of sensitization of U937 cells varied being greatest with TRAIL-His-LE $\approx$ TRAIL-His $>$ Apo2L/ TRAIL $\gg$ HGS-ETR2 $\approx$ HGS-ETR1, with TRAIL-His-LE and TRAIL-His being $\sim 5$-fold more potent than Apo2L/TRAIL.

To confirm that the depsipeptide mediated-sensitization was due to apoptosis, we again examined the effects of the different treatments on caspase processing. In untreated U937 cells, caspase- 3 and caspase-8 were present primarily as their unprocessed zymogens (Figure 3b lane 1). In U937 cells exposed to depsipeptide $(10 \mathrm{nM})$ or valproate $(2.5 \mathrm{mM})$ alone or to TRAIL-His $(100 \mathrm{ng} / \mathrm{ml})$, TRAIL-His-LE $(100 \mathrm{ng} / \mathrm{ml})$, Apo2L/TRAIL $(500 \mathrm{ng} / \mathrm{ml})$ and HGS-ETR1 $(1 \mu \mathrm{g} / \mathrm{ml})$ alone, which did not induce any apoptosis, no processing of either caspase-3 or caspase-8 was observed (Figure 3b lanes 2-4, $7,10,13$ and 16 , respectively). In contrast, in cells pretreated with either depsipeptide or valproate, processing of both caspase- 8 to its $p 43$ and p41 fragments and caspase- 3 to its p19 and p17 forms was observed in U937 cells exposed to TRAIL-His, TRAIL-His-LE and Apo2L/TRAIL (Figure $3 b$ lanes $5,6,8,9,11$ and 12), commensurate with their induction of apoptosis. Much smaller amounts of processed caspase-8 and caspase-3 were observed in cells pretreated with depsipeptide or valproate and subsequently exposed to
HGS-ETR1 or HGS-ETR2 (Figure $3 b$ lanes 14, 15, 17 and 18), commensurate with the lower levels of apoptosis induced by the agonistic mAbs.

Depsipeptide $(10 \mathrm{nM})$, valproate $(2 \mathrm{mM})$, TRAIL-His (10$100 \mathrm{ng} / \mathrm{ml})$, TRAIL-His-LE $(10-100 \mathrm{ng} / \mathrm{ml})$, Apo2L/TRAIL $(10-500 \mathrm{ng} / \mathrm{ml})$, HGS-ETR1 $(50-1000 \mathrm{ng} / \mathrm{ml})$ or HGS-ETR2 $(50-1000 \mathrm{ng} / \mathrm{ml})$ alone induced little or no apoptosis in K562 cells (Figure 4a). Pretreatment with depsipeptide or valproate sensitized K562 cells to the different TRAIL preparations except HGS-ETR1, with depsipeptide being somewhat more effective than valproate (Figure 4a). Marked differences in the efficacy of the different TRAIL preparations to induce apoptosis was noted compared to CLL cells with Apo2L/TRAIL > TRAIL-His-LE $\approx$ TRAIL-His $>$ HGSETR2 $>>>$ HGS-ETR1. The greater potency of the Apo2L/ TRAIL was most evident at low concentrations of the ligand (Figure 4a). In K562 cells, caspase-3 and caspase-8 were again processed commensurate with the induction of apoptosis induced by the different preparations of TRAIL (Figure 4b). Taken together, these data demonstrate that both depsipeptide and valproate can sensitize U937 and K562 cells to TRAIL-induced apoptosis.

\section{Cell surface receptor expression in tumor cell lines}

Differences in cell surface expression of TRAIL-R1 and -R2 receptors may partially explain the variation in activities of

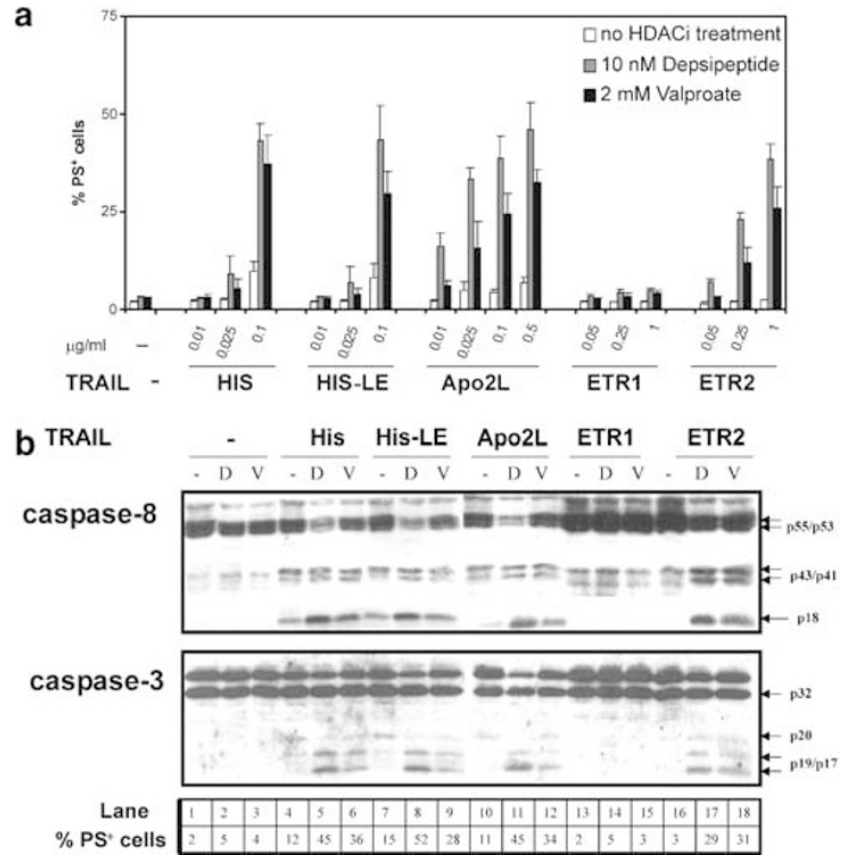

Figure 4 HDAC inhibitors sensitize K562 cells to TRAIL-induced apoptosis by signaling through TRAIL-R2. K562 cells were incubated either alone or with depsipeptide (D) $(10 \mathrm{nM})$ or sodium valproate (V) $(2 \mathrm{mM})$ for $12 \mathrm{~h}$ and then exposed to the indicated concentrations of TRAIL-His (His), TRAIL-His-LE (His$\mathrm{LE}$ ) or Apo2L/TRAIL (Apo2L) or to the agonistic mAbs as described in the legend to Figure 1. (a) Apoptosis was assessed by measurement of phosphatidylserine (PS) externalization. The results shown represent the Mean \pm S.E.M. of three separate determinations. (b) Apoptosis was also assessed by processing of caspase- 8 and -3 
different TRAIL preparations, although it has been shown that cell surface receptor expression alone does not account for the differential sensitivity of different cell lines to TRAIL. ${ }^{13,32,33}$ U937 cells display significant surface expression of TRAIL-R2 with little or no surface expression of TRAIL-R1 (Figure 5a). Following treatment of U937 cells with depsipeptide (10 nM) for $8 \mathrm{~h}$, surface expression of TRAIL-R1 was unchanged whereas that of TRAIL-R2 increased slightly (Figure 5a). K562 cells displayed high and low levels of surface expression of TRAIL-R1 and TRAIL-R2, respectively (Figure 5a) but following treatment with depsipeptide, surface expression of TRAIL-R2 increased markedly whereas that of TRAIL-R1 decreased markedly (Figure 5a). Previously we have shown that CLL cells express low levels of both TRAIL-R1 and -R2 receptors but cell surface receptor expression alone does not correlate with susceptibility to apoptosis. ${ }^{14,17}$ Taken together, the data in CLL, K562 and U937 cells demonstrated that there was no clear relationship between cell surface expression of TRAIL-R1 or -R2 and sensitivity to TRAIL-induced apoptosis. Clearly other factors also influence the ability of the receptor to signal for apoptosis. ${ }^{13,17,32,33}$

\section{Apo2L/TRAIL induces apoptosis primarily via signaling through TRAIL-R2}

Although the various TRAIL preparations were active, their activity was clearly dependent on the target cell line or pretreatment with an HDACi. TRAIL-His and TRAIL-His-LE were more potent than Apo2L/TRAIL in U937 cells (Figure 3a) and also in CLL cells (Figures 1a and c), which appear to signal almost exclusively through TRAIL-R1 (Figure 1b and c). However, in K562 cells following HDACi treatment, Apo2L/ TRAIL was clearly the most potent particularly at low concentrations and in these cells HGS-ETR2 was much more active than HGS-ETR1 (Figure 4a). Taken together with the other data, this supports the hypothesis that Apo2L/TRAIL is active primarily by signaling through TRAIL-R2. This hypothesis is also consistent with TRAIL having a higher affinity for TRAIL-R2 than other receptors at physiological temperatures. ${ }^{34}$ These results also suggested that Apo2L/TRAIL was relatively weak at inducing apoptosis via TRAIL-R1, whereas TRAIL-His and TRAIL-His-LE could induce apoptosis by signaling through either TRAIL-R1 or -R2.

To further test this hypothesis, we examined the sensitivity of a cell line that expresses primarily TRAIL-R1 and is sensitive to a TRAIL-R1 mAb, predicting that these cells should be relatively insensitive to Apo2L/TRAIL. Ramos cells expressed primarily cell surface TRAIL-R1 together with a low

Figure 5 Apo2L/TRAIL induces apoptosis via TRAIL-R2. Cell surface expression levels of TRAIL-R1 and -R2 were measured in (a) U937, K562, Ramos and Jurkat cells. Cells were cultured either alone (gray shading) or in the presence of depsipeptide $(10 \mathrm{nM}$ ) (dark black line) for $8 \mathrm{~h}$ and surface expression assessed by flow cytometry using mAbs to TRAIL-R1 and -R2. Cells labeled with control $\mathrm{Ab}$ alone were used to control for background fluorescence (pale line - no shading). (b) Ramos cells and (c) Jurkat cells were incubated for 4 or $8 \mathrm{~h}$, respectively, with the indicated concentrations of TRAIL-His (His), TRAIL-His-LE (His-LE) or Apo2L/TRAIL (Apo2L) or to the agonistic mAbs and apoptosis assessed by phosphatidylserine (PS) externalization. Results are the Mean \pm S.E.M. of at least three separate determinations surface expression of TRAIL-R2 (Figure 5a). Exposure of Ramos cells to HGS-ETR1 but not HGS-ETR2 showed a concentration-dependent induction of apoptosis (Figure $5 \mathrm{~b}$ ), suggesting that the TRAIL-R1 but not the TRAIL-R2 receptor was active. A dose response comparison of Ramos cells to the different forms of TRAIL showed that the cells were more
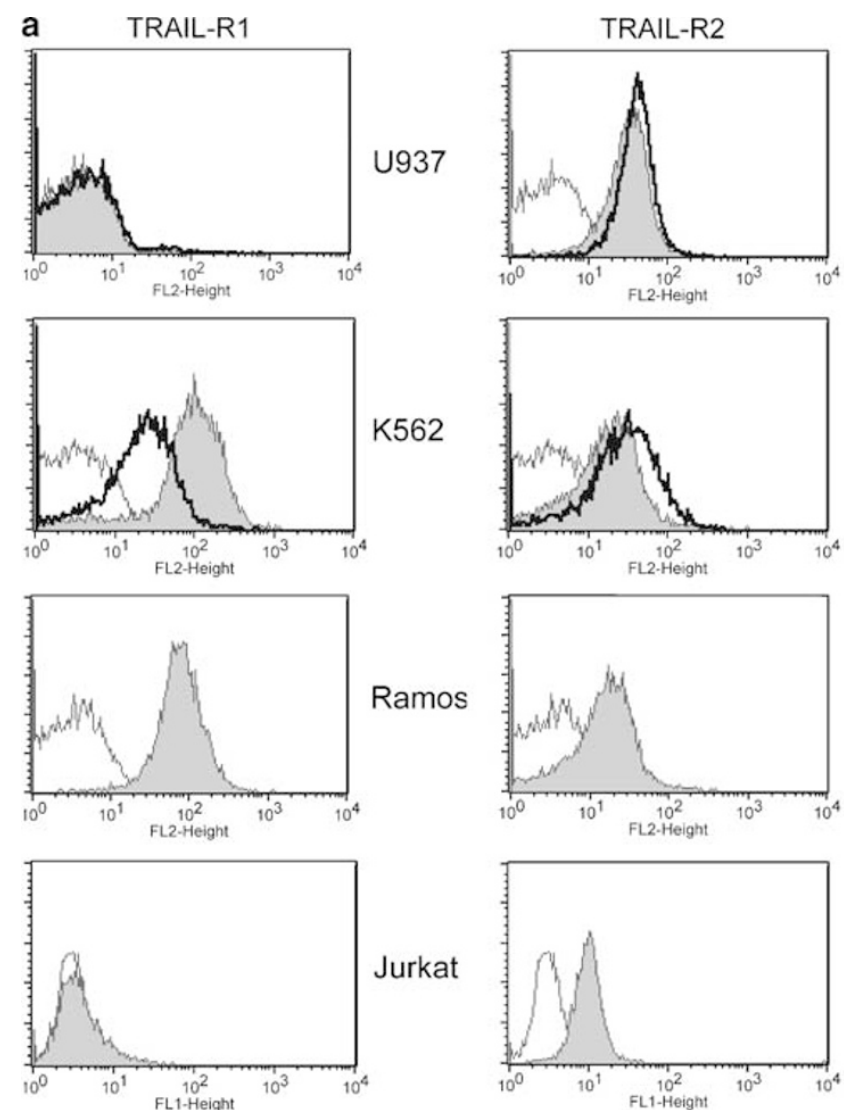

b
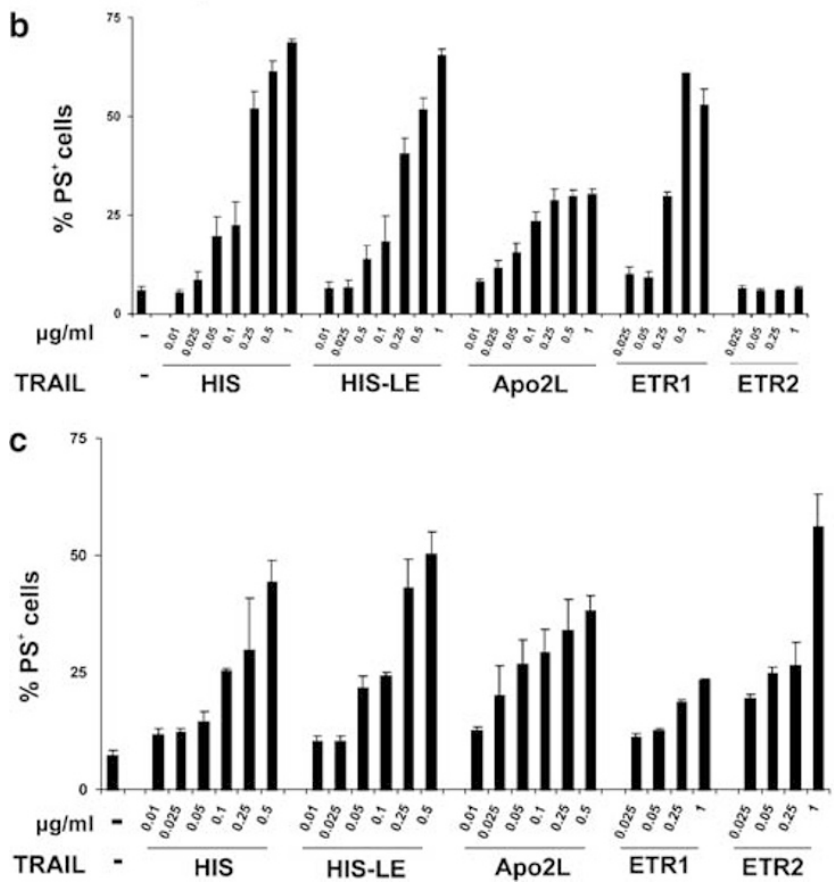
sensitive to TRAIL-His, TRAIL-His-LE and HGS-ETR1 than to Apo2L/TRAIL. Exposure of the Ramos cells for a further $4 \mathrm{~h}$ to Apo2L/TRAIL $(1000 \mathrm{ng} / \mathrm{ml})$ resulted in only a small increase of apoptosis from 28 to $39 \%$. We also examined the sensitivity of Jurkat $T$ cells that express surface TRAIL-R2 with no detectable surface expression of TRAIL-R1 (Figure 5a). As expected, these cells were more susceptible to HGS-ETR2 than HGS-ETR1 (Figure 5c). At low concentrations of the ligands, Apo2L/TRAIL appeared somewhat more potent than TRAIL-His and TRAIL-His-LE (Figure 5c). Taken together, these results were compatible with the suggestion that Apo2L/ TRAIL signals primarily through TRAIL-R2, whereas TRAILHis and TRAIL-His-LE can signal through both TRAIL-R1 and -R2, possibly with a preference for TRAIL-R1.

\section{Discussion}

Many hematological malignancies, including CLL, remain incurable with current therapy. Overall survival has not improved significantly despite the introduction of new therapeutic agents and the prognosis for certain subgroups of patients, particularly for those with either clinical resistance to fludarabine or mutations of $\mathrm{p} 53$, is measured in months. ${ }^{28,29}$ New therapeutic approaches are urgently needed for CLL and related B-cell malignancies.

Significantly, different preparations of TRAIL varied markedly in their ability to induce apoptosis in vitro and they acted preferentially via either TRAIL-R1 or -R2 (Figures 1, 3-5). The molecular basis for this selective activation via the two receptors is not known, but together with the data using the receptor-specific mAbs implicates independent regulation of signaling via homotrimeric TRAIL-R1 and -R2 receptors. In addition, sensitivity to the various reagents could not be predicted on the basis of receptor level expression alone. In CLL cells signaling to apoptosis occurred predominantly, if not exclusively, via TRAIL-R1 (Figure 1) despite surface expression of TRAIL-R2. ${ }^{14,17}$ Taken together, our data strongly suggest that it may be essential to test individual tumor types functionally with TRAIL rather than simply on the presence or absence of cell surface TRAIL receptor expression.

We propose that an HDACi in combination with TRAIL or an appropriate $\mathrm{mAb}$ signaling predominantly through TRAIL-R1 may be effective therapy for CLL, including patients refractory to fludarabine or with p53 mutations. The possible clinical use of an HDACi has not been extensively investigated in CLL. Sodium valproate acts as an HDACi in CLL cells as evidenced by an increase in acetylated $\mathrm{H} 3$ and $\mathrm{H} 4$ (data not shown). Doses of sodium valproate, resulting in serum concentrations of $346-693 \mu \mathrm{M}$ have been used in patients with myelodysplasia without serious toxicities. ${ }^{35}$ In preliminary studies, valproate $(0.75 \mathrm{mM})$ potentiated TRAIL-induced apoptosis in CLL cells of some but not all patients. In the present study, valproate $(2 \mathrm{mM})$ was used to ensure a response in all patients but prior to entering a clinical trial, the lowest concentration of valproate that sensitizes CLL cells to TRAIL could be ascertained on an individual basis. HDAC inhibition is a simple means of overcoming TRAIL resistance and may operate in solid malignancies as well as hematological diseases, although the molecular mechanism underlying this phenomenon remains unclear. ${ }^{18,19,36}$ Based on our current data, we propose that valproate in combination with the agonistic Ab, HGS-ETR1, or alternatively a form of TRAIL that signals predominantly through TRAIL-R1, could be used to obtain proof of principle for the concept of the therapeutic benefit of such combinations. Interestingly, HGS-ETR1 alone was also devoid of activity in CLL cells and activity was only manifested in combination with an HDACi.

Although most studies suggest that TRAIL-R2 is the primary TRAIL receptor leading to cell death, ${ }^{9,11,37,38}$ few studies have used primary tumor cells from patients; the great majority having utilized cell lines. TRAIL had a modest activity in killing primary precursor B-cell acute lymphoblastic leukemic (ALL) cells but no correlation was seen with the levels of receptor expression. ${ }^{13}$ Primary multiple myeloma cells are also killed by TRAIL but the receptor involved is not known. ${ }^{39}$ Upregulation of TRAIL-R2 was found in several human tumors including liver, breast, and 5/8 lymphomas examined, although changes in TRAIL-R1 were not assessed. ${ }^{38}$ In this study, the tumoricidal effect of an agonistic TRAIL-R2 Ab was observed without any hepatocyte toxicity. ${ }^{38}$ It is presently unclear whether our finding that primary CLL cells signal through TRAIL-R1 is restricted to malignant cells of hematopoietic origin or may be a more general feature of primary tumor cells.

Another interesting aspect of the requirement to signal through TRAIL-R1 relates to the potential effects on liver toxicity. The potential of TRAIL to induce liver toxicity was first proposed following its induction of apoptosis in normal primary human hepatocytes. ${ }^{12}$ This caused particular concern due to the known liver toxicity of CD95. ${ }^{40}$ Although the toxicity was ascribed to the use of nonoptimized TRAIL preparations, which contain poor zinc coordination and a less ordered conformation, ${ }^{11,41}$ it may also have been due to enhanced oligomerization of TRAIL caused by dithiothreitol present in the purification procedure. ${ }^{42}$ In the present study, we used two forms of His-TRAIL. Analysis of one of these forms, TRAILHis-LE, showed that it was $>99 \%$ pure and did not contain dimers or trimers by SDS-PAGE analysis (Alexis Corp.). There are conflicting reports on the presence of TRAIL receptors in human liver. Both TRAIL-R1 and -R2 were proposed to be on the cell surface by virtue of their susceptibility to agonistic mAbs. ${ }^{43}$ However, another study proposed an absence of cell surface TRAIL-R2 by virtue of its insensitivity to an agonistic mAb. ${ }^{38}$ Most recently it has been shown that freshly isolated human hepatocytes express no TRAIL-R1 and very small amounts of TRAIL-R2 on the cell surface. ${ }^{44}$ In this elegant study, TRAIL was not hepatotoxic in severe combined immunodeficient/Alb-uPA chimeric mice containing human hepatocytes. ${ }^{44}$ Thus, the proposed combination of an HDACi and an agonistic TRAIL-R1 Ab should not exacerbate any potential liver toxicity.

Taken together our results strongly suggest that subtle alterations in different forms of TRAIL can alter their propensity to activate different TRAIL receptors, thus markedly altering their biological activities. The presence of the His-tag or some other change occurring during the purification of both TRAIL-His and TRAIL-His-LE has possibly resulted in a subtle conformational change enabling the ligand to activate more selectively TRAIL-R1. In this regard it is interesting to consider a recent study, ${ }^{37}$ which showed that mutation of 
certain residues in Apo2L/TRAIL resulted in selective binding to either TRAIL-R1 or -R2. As the TRAIL-R2, but not the TRAIL-R1-selective variants, induced apoptosis in selected cell lines, the authors concluded that signaling through TRAIL$\mathrm{R} 2$ rather than -R1 may be more important in TRAIL-induced apoptosis in cancer cells expressing both receptors. ${ }^{37}$ However, our results suggest that this conclusion is dependent at least in part on the cell lines used. Nevertheless, subtle conformational changes of the TRAIL ligand clearly affect its ability to interact selectively with different receptors. ${ }^{37}$ In support of their findings, we clearly show that Apo2L/TRAIL is more active than other forms of TRAIL in cells that signal primarily through TRAIL-R2, namely K562 cells (Figure 4a) and to a lesser extent in Jurkat cells (Figure 5c). However, Apo2L/TRAIL is virtually devoid of activity in cells that signal primarily through TRAIL-R1, namely CLL and Ramos cells (Figures 1 and 5). As Apo2L/TRAIL (Genentech) has just entered Phase I clinical trials, our data highlight the importance of assessing the selectivity of different primary tumors to signaling via TRAIL-R1 or -R2 prior to commencement of treatment. Prior knowledge of whether a tumor is activated via TRAIL-R1 or -R2 to induce apoptosis before initiating therapy will facilitate the choice of an appropriate preparation of TRAIL, so maximizing the therapeutic ratio by averting any possible toxicity due to the use of therapeutically inactive TRAIL preparations.

In summary, our data indicate an unanticipated preferential apoptotic signaling via either TRAIL-R1 or -R2 in tumor cells. Thus the rational clinical use of TRAIL-targeted therapy will require prior in vitro testing to assess the sensitivities of different tumors to TRAIL-R1 or -R2.

\section{Materials and Methods}

\section{Lymphocyte purification, cell lines and culture}

Blood samples were obtained from CLL patients, staged according to the Binet system, during routine diagnosis at the Leicester Royal Infirmary with patient consent and local ethical committee approval. Blood samples were analyzed while patients were no longer receiving any chemotherapy. CLL cells were purified as previously described ${ }^{14,17}$ resulting in mean average

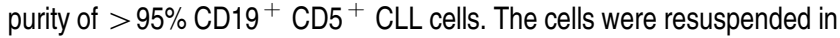
RPMl 1640 medium $\left(5 \times 10^{6} \mathrm{cell} / \mathrm{sl}\right)$ at $37^{\circ} \mathrm{C}$ in an atmosphere of $5 \%$ $\mathrm{CO}_{2}$ and incubated with different preparations of TRAIL or agonistic mAbs to TRAIL-R1 or TRAIL-R2. Cells were also incubated with depsipeptide $(10 \mathrm{nM})$ or sodium valproate $(1-2.5 \mathrm{mM})$ for the indicated times $(8-16 \mathrm{~h})$ prior to treatment with TRAIL. U937, K562 and Jurkat T cells (clone E6-1) were cultured as previously described. ${ }^{17}$ Ramos, an Epstein-Barr virusnegative Burkitt's lymphoma cell line, was maintained in RPMI 1640 medium supplemented with $10 \%$ fetal bovine serum (FBS), penicillin $(100 \mathrm{U} / \mathrm{ml})$ and streptomycin $(100 \mu \mathrm{g} / \mathrm{ml})$. Parental and p53 ${ }^{-1-}$ HCT116 cells (provided by Dr. B Vogelstein) were maintained in McCoy's $5 \mathrm{~A}$ medium supplemented with 10\% FBS and Glutamax. Samples were either analyzed immediately for apoptosis or pelleted and stored at $-80^{\circ} \mathrm{C}$ for subsequent Western blotting.

\section{Materials}

Media and serum were from Life Technologies, Inc. (Paisley, UK). TRAILHis-LE (a recombinant TRAIL with low endotoxin - Lot L11447), which was
$>99 \%$ pure and did not contain dimers or trimers by SDS-PAGE analysis, was obtained from Alexis Corporation (Nottingham, UK). A similar form of human recombinant TRAIL-His was prepared as previously described (but not further purified to reduce endotoxin levels). ${ }^{14}$ Apo2L/TRAIL (Genentech), and HGS-ETR1 and HGS-ETR2 were kindly provided by Genentech (South San Francisco, CA, USA) and Human Genome Sciences (Rockville, MD, USA), respectively. Phycoerythrin (PE)-conjugated mouse anti-DR4 and anti-DR5 $\mathrm{mAb}$ for flow cytometric detection of cell surface expression of TRAIL-R1 and -R2, respectively, were from eBiosciences Inc. (San Diego, CA, USA). Depsipeptide was kindly provided by Dr. E Sausville ( $\mathrm{NCl}, \mathrm{USA}$ ) and sodium valproate was from Calbiochem (Nottingham, UK). Caspase antibodies were from sources previously described. ${ }^{45}$ Other reagents were from Sigma (Poole, UK).

\section{Quantification of apoptosis and Western blot analysis}

Apoptosis was quantified by phosphatidylserine (PS) externalization in the presence of propidium iodide as previously described. ${ }^{14}$ Samples for Western blot analysis were prepared and the processing of caspase- 3 and -8 was detected as previously described. ${ }^{46}$

\section{Assessment of cell surface receptor expression}

Cells were resuspended in blocking buffer ( $10 \%$ normal goat serum in PBS) and incubated for 30 min on ice to block nonspecific binding, then incubated with anti-TRAIL receptor antibodies (diluted 1:25) or an isotype-matched control antibody for $1 \mathrm{~h}$ on ice, washed three times with PBS and then analyzed as previously described. ${ }^{14,17}$

\section{p53 analysis}

DNA was extracted from peripheral blood lymphocytes using the DNeasy tissue kit (Qiagen,West Sussex, UK) according to the manufacturer's instructions. PCR was performed using $100 \mathrm{ng}$ of DNA, $2 \mu \mathrm{M}$ of each primer and $12.5 \mu \mathrm{l}$ of Extensor readymix (Abgene, Surrey, UK). Cycling parameters were denaturation at $94^{\circ}$ for $5 \mathrm{~min}$, followed by 35 cycles of denaturation $\left(94^{\circ}\right.$ for $\left.15 \mathrm{~s}\right)$, annealing $\left(60^{\circ}\right.$ for $\left.30 \mathrm{~s}\right)$, extension $\left(68^{\circ}\right.$ for $30 \mathrm{~s}$ ) and a final extension at $72^{\circ}$ for $10 \mathrm{~min}$ in a Techne Touchgene gradient thermal cycler. Primers were generated as described for exons $5-9^{47}$ and exon $4 .^{48}$

\section{IGHV analysis}

IGHV analysis was performed using genomic DNA as a template as previously described using the BIOMED2 primers. ${ }^{49}$ When more than one rearranged IGHV allele was detected, the PCR products were gel eluted and purified using the Qiaquick gel extraction kit (Qiagen) according to the manufacturer's instructions. Homology of the rearranged IGHV sequences with the germline IGHV sequences was determined using IgBlast at the NCBI (http://www.ncbi.nlm.nih.gov/BLAST/) and aligned using CLUSTALW (http://www.ebi.ac.uk/clustalw/).

\section{Acknowledgements}

We thank Genentech for the kind supply of Apo2L/TRAIL and Human Genome Sciences for the agonisitic mAbs. Parental and p53 ${ }^{-1-}$ HCT116 cells were a kind gift from Dr. B Vogelstein (John Hopkins University, Baltimore). 


\section{References}

1. Ashkenazi A, Pai RC, Fong S, Leung S, Lawrence DA, Marsters SA, Blackie C Chang L, McMurtrey AE, Hebert A, DeForge L, Koumenis IL, Lewis D, Harris L, Bussiere J, Koeppen H, Shahrokh Z and Schwall RH (1999) Safety and antitumor activity of recombinant soluble Apo2 ligand. J. Clin. Invest. 104: $155-162$

2. Wiley SR, Schooley K, Smolak PJ, Din WS, Huang CP, Nicholl JK, Sutherland GR, Smith TD, Rauch C, Smith CA and Goodwin RG (1995) Identification and characterization of a new member of the TNF family that induces apoptosis. Immunity 3: 673-682

3. Pitti RM, Marsters SA, Ruppert S, Donahue CJ, Moore A and Ashkenazi A (1996) Induction of apoptosis by Apo-2 ligand, a new member of the tumor necrosis factor cytokine family. J. Biol. Chem. 271: 12687-12690

4. Walczak H, Miller RE, Ariail K, Gliniak B, Griffith TS, Kubin M, Chin W, Jones J, Woodward A, Le T, Smith C, Smolak P, Goodwin RG, Rauch CT, Schuh JC and Lynch DH (1999) Tumoricidal activity of tumor necrosis factor-related apoptosis-inducing ligand in vivo. Nat. Med. 5: 157-163

5. Bodmer JL, Holler N, Reynard S, Vinciguerra P, Schneider P, Juo P, Blenis J and Tschopp J (2000) TRAIL receptor-2 signals apoptosis through FADD and caspase-8. Nat. Cell Biol. 2: 241-243

6. Kischkel FC, Lawrence DA, Chuntharapai A, Schow P, Kim KJ and Ashkenazi A (2000) Apo2L/TRAIL-dependent recruitment of endogenous FADD and caspase-8 to death receptors 4 and 5 . Immunity 12 : 611-620

7. Sprick MR, Weigand MA, Rieser E, Rauch CT, Juo P, Blenis J, Krammer PH and Walczak H (2000) FADD/MORT1 and caspase-8 are recruited to TRAIL receptors 1 and 2 and are essential for apoptosis mediated by TRAIL receptor 2. Immunity 12: 599-609

8. Bratton SB, MacFarlane M, Cain K and Cohen GM (2000) Protein complexes activate distinct caspase cascades in death receptor and stress-induced apoptosis. Exp. Cell Res. 256: 27-33

9. Ashkenazi A (2002) Targeting death and decoy receptors of the tumournecrosis factor superfamily. Nat. Rev. Cancer 2: $420-430$

10. Ashkenazi A and Dixit VM (1998) Death receptors: signaling and modulation. Science 281: 1305-1308

11. LeBlanc HN and Ashkenazi A (2003) Apo2L/TRAIL and its death and decoy receptors. Cell Death Differ. 10: 66-75

12. Jo M, Kim TH, Seol DW, Esplen JE, Dorko K, Billiar TR and Strom SC (2000) Apoptosis induced in normal human hepatocytes by tumor necrosis factorrelated apoptosis-inducing ligand. Nat. Med. 6: 564-567

13. Clodi K, Wimmer D, Li Y, Goodwin R, Jaeger U, Mann G, Gadner H and Younes A (2000) Expression of tumour necrosis factor (TNF)-related apoptosisinducing ligand (TRAIL) receptors and sensitivity to TRAIL-induced apoptosis in primary B-cell acute lymphoblastic leukaemia cells. Br. J. Haematol. 111: 580-586

14. MacFarlane M, Harper N, Snowden RT, Dyer MJ, Barnett GA, Pringle JH and Cohen GM (2002) Mechanisms of resistance to TRAlL-induced apoptosis in primary B cell chronic lymphocytic leukaemia. Oncogene 21: 6809-6818

15. Snell V, Clodi K, Zhao S, Goodwin R, Thomas EK, Morris SW, Kadin ME, Cabanillas F, Andreeff M and Younes A (1997) Activity of TNF-related apoptosis-inducing ligand (TRAIL) in haematological malignancies. Br. J. Haematol. 99: 618-624

16. Shankar S and Srivastava RK (2004) Enhancement of therapeutic potential of TRAIL by cancer chemotherapy and irradiation: mechanisms and clinical implications. Drug Resist. Update 7: 139-156

17. Inoue S, MacFarlane M, Harper N, Wheat LM, Dyer MJ and Cohen GM (2004) Histone deacetylase inhibitors potentiate TNF-related apoptosis-inducing ligand (TRAIL)-induced apoptosis in lymphoid malignancies. Cell Death Differ. 11 (Suppl 2): S193-206

18. Marks P, Rifkind RA, Richon VM, Breslow R, Miller T and Kelly WK (2001) Histone deacetylases and cancer: causes and therapies. Nat. Rev. Cancer 1 : 194-202

19. Marks PA, Miller T and Richon VM (2003) Histone deacetylases. Curr. Opin Pharmacol. 3: 344-351

20. Dobson C, Edwards B, Main S, Minter R, Williams L, Salcedo T, Choi G, Albert $V$ and Vaughan T (2002) Generation of human therapeutic anti-TRAIL-R1 agonistic antibody by phage display. Proc. Amer. Assoc. Cancer Res. (Abstract \#2869)
21. Johnson R, Huang X, Fiscella M, Cole C, Pukac L, Von Kerczek A, Humphreys R, Grzegorzewski K, Gallant G and Albert V (2003) Human agonistic antiTRAIL receptor antibodies, HGS-ETR1 and HGS-ETR2, induce apoptosis in diverse hematological tumor cell lines. Blood 102 (Abstract \#3316)

22. Thomas LR, Johnson RL, Reed JC and Thorburn A (2004) The C-terminal tails of tumor necrosis factor-related apoptosis-inducing ligand (TRAIL) and Fas receptors have opposing functions in Fas-associated Death Domain (FADD) recruitment and can regulate agonist-specific mechanisms of receptor activation. J. Biol. Chem. 279: 52479-52486

23. MacFarlane M, Ahmad M, Srinivasula SM, Fernandes-Alnemri T, Cohen GM and Alnemri ES (1997) Identification and molecular cloning of two novel receptors for the cytotoxic ligand TRAIL. J. Biol. Chem. 272: 25417-25420

24. Phiel CJ, Zhang F, Huang EY, Guenther MG, Lazar MA and Klein PS (2001) Histone deacetylase is a direct target of valproic acid, a potent anticonvulsant, mood stabilizer, and teratogen. J. Biol. Chem. 276: 36734-36741

25. Gottlicher M, Minucci S, Zhu P, Kramer OH, Schimpf A, Giavara S, Sleeman JP, Lo Coco F, Nervi C, Pelicci PG and Heinzel T (2001) Valproic acid defines a novel class of HDAC inhibitors inducing differentiation of transformed cells. EMBO J. 20: 6969-6978

26. MacFarlane M, Merrison W, Dinsdale D and Cohen GM (2000) Active caspases and cleaved cytokeratins are sequestered into cytoplasmic inclusions in TRAILinduced apoptosis. J. Cell Biol. 148: 1239-1254

27. Bunz F, Dutriaux A, Lengauer C, Waldman T, Zhou S, Brown JP, Sedivy JM, Kinzler KW and Vogelstein B (1998) Requirement for p53 and p21 to sustain G2 arrest after DNA damage. Science 282: 1497-1501

28. Dohner H, Stilgenbauer S, Benner A, Leupolt E, Krober A, Bullinger L, Dohner $\mathrm{K}$, Bentz $\mathrm{M}$ and Lichter $\mathrm{P}$ (2000) Genomic aberrations and survival in chronic lymphocytic leukemia. N. Engl. J. Med. 343: 1910-1916

29. Perkins JG, Flynn JM, Howard RS and Byrd JC (2002) Frequency and type of serious infections in fludarabine-refractory B-cell chronic lymphocytic leukemia and small lymphocytic lymphoma: implications for clinical trials in this patient population. Cancer 94: 2033-2039

30. Hamblin TJ, Davis Z, Gardiner A, Oscier DG and Stevenson FK (1999) Unmutated $\lg \mathrm{V}(\mathrm{H})$ genes are associated with a more aggressive form of chronic lymphocytic leukemia. Blood 94: 1848-1854

31. Damle RN, Wasil T, Fais F, Ghiotto F, Valetto A, Allen SL, Buchbinder A, Budman D, Dittmar K, Kolitz J, Lichtman SM, Schulman P, Vinciguerra VP, Rai KR, Ferrarini M and Chiorazzi N (1999) lg V gene mutation status and CD38 expression as novel prognostic indicators in chronic lymphocytic leukemia. Blood 94: 1840-1847

32. Kim K, Fisher MJ, Xu SQ and el-Deiry WS (2000) Molecular determinants of response to TRAIL in killing of normal and cancer cells. Clin. Cancer Res. 6: 335-346

33. Kang J, Kisenge RR, Toyoda H, Tanaka S, Bu J, Azuma E and KomadaY (2003) Chemical sensitization and regulation of TRAIL-induced apoptosis in a panel of B-lymphocytic leukaemia cell lines. Br. J. Haematol. 123: 921-932

34. Truneh A, Sharma S, Silverman C, Khandekar S, Reddy MP, Deen KC, McLaughlin MM, Srinivasula SM, Livi GP, Marshall LA, Alnemri ES, Williams WV and Doyle ML (2000) Temperature-sensitive differential affinity of TRAIL for its receptors. DR5 is the highest affinity receptor. J. Biol. Chem. 275: 23319-23325

35. Kuendgen A, Strupp C, Aivado M, Bernhardt A, Hildebrandt B, Haas R, Germing U and Gattermann N (2004) Treatment of myelodysplastic syndromes with valproic acid alone or in combination with all-trans retinoic acid. Blood 104: 1266-1269

36. Melnick A and Licht JD (2002) Histone deacetylases as therapeutic targets in hematologic malignancies. Curr. Opin. Hematol. 9: 322-332

37. Kelley RF, Totpal K, Lindstrom SH, Mathieu M, Billeci K, Deforge L, Pai R, Hymowitz SG and Ashkenazi A (2005) Receptor-selective mutants of apoptosis-inducing ligand 2L/tumor necrosis factor-related apoptosis-inducing ligand reveal a greater contribution of death receptor (DR) 5 than DR4 to apoptosis signaling. J. Biol. Chem. 280: 2205-2212

38. Ichikawa K, Liu W, Zhao L, Wang Z, Liu D, Ohtsuka T, Zhang H, Mountz JD, Koopman WJ, Kimberly RP and Zhou T (2001) Tumoricidal activity of a novel anti-human DR5 monoclonal antibody without hepatocyte cytotoxicity. Nat. Med. 7: 954-960

39. Mitsiades CS, Treon SP, Mitsiades N, Shima Y, Richardson P, Schlossman R, Hideshima T and Anderson KC (2001) TRAIL/Apo2L ligand selectively induces 
apoptosis and overcomes drug resistance in multiple myeloma: therapeutic applications. Blood 98: 795-804

40. Ogasawara J, Watanabe-Fukunaga R, Adachi M, Matsuzawa A, Kasugai T, Kitamura Y, Itoh N, Suda T and Nagata S (1993) Lethal effect of the anti-Fas antibody in mice. Nature 364: 806-809

41. Lawrence D, Shahrokh Z, Marsters S, Achilles K, Shih D, Mounho B, Hillan K, Totpal K, DeForge L, Schow P, Hooley J, Sherwood S, Pai R, Leung S, Khan L, Gliniak B, Bussiere J, Smith CA, Strom SS, Kelley S, Fox JA, Thomas D and Ashkenazi A (2001) Differential hepatocyte toxicity of recombinant Apo2L/ TRAIL versions. Nat. Med. 7: 383-385

42. Kim SH, Kim K, Kwagh JG, Dicker DT, Herlyn M, Rustgi AK, Chen Y and El-Deiry WS (2004) Death induction by recombinant native TRAIL and its prevention by a caspase 9 inhibitor in primary human esophageal epithelial cells. J. Biol. Chem. 279: 40044-40052

43. Mori E, Thomas M, Motoki K, Nakazawa K, Tahara T, Tomizuka K, Ishida I and Kataoka S (2004) Human normal hepatocytes are susceptible to apoptosis signal mediated by both TRAIL-R1 and TRAIL-R2. Cell Death Differ. 11: 203-207

44. Hao C, Song JH, Hsi B, Lewis J, Song DK, Petruk KC, Tyrrell DL and Kneteman NM (2004) TRAIL inhibits tumor growth but is nontoxic to human hepatocytes in chimeric mice. Cancer Res. 64: 8502-8506
45. Sun XM, Bratton SB, Butterworth M, MacFarlane M and Cohen GM (2002) $\mathrm{BCl}-2$ and $\mathrm{Bcl}-\mathrm{xL}$ inhibit CD95-mediated apoptosis by preventing mitochondrial release of Smac/DIABLO and subsequent inactivation of X-linked inhibitor-ofapoptosis protein. J. Biol. Chem. 277: 11345-11351

46. Sun XM, MacFarlane M, Zhuang J, Wolf BB, Green DR and Cohen GM (1999) Distinct caspase cascades are initiated in receptor-mediated and chemicalinduced apoptosis. J. Biol. Chem. 274: 5053-5060

47. Lens D, De Schouwer PJ, Hamoudi RA, Abdul-Rauf M, Farahat N, Matutes E, Crook T, Dyer MJ and Catovsky D (1997) p53 abnormalities in B-cell prolymphocytic leukemia. Blood 89: 2015-2023

48. Thornton PD, Gruszka-Westwood AM, Hamoudi RA, Atkinson S, Kaczmarek P, Morilla RM, Hilditch BL, A'Hern R, Matutes E and Catovsky D (2004) Characterisation of TP53 abnormalities in chronic lymphocytic leukaemia. Hematol. J. 5: 47-54

49. van Dongen JJ, Langerak AW, Bruggemann M, Evans PA, Hummel M, Lavender FL, Delabesse E, Davi F, Schuuring E, Garcia-Sanz R, van Krieken JH, Droese J, Gonzalez D, Bastard C, White HE, Spaargaren M, Gonzalez M, Parreira A, Smith JL, Morgan GJ, Kneba M and Macintyre EA (2003) Design and standardization of PCR primers and protocols for detection of clonal immunoglobulin and T-cell receptor gene recombinations in suspect lymphoproliferations: report of the BIOMED-2 Concerted Action BMH4-CT98-3936. Leukemia 17: 2257-2317 